\title{
Crithidia deanei infection in normal and dexamethasone-immunosuppressed Balb/c mice
}

\author{
Dilvani Oliveira Santos ${ }^{1 *}$, Saulo C. Bourguignon ${ }^{1}$, Helena Carla Castro ${ }^{1}$, Alice Miranda ${ }^{2,3}$, \\ Rodrigo Tonioni Vieira ${ }^{1}$, Suzana Corte-Real ${ }^{4}$, Otílio Machado Pereira Bastos ${ }^{5}$ \\ ${ }^{1}$ Department of Cellular and Molecular Biology, Federal Fluminense University (UFF), Rio de Janeiro, Brazil; \\ *Corresponding Author: santosdilvani@gmail.com; lacelauff@yahoo.com.br \\ ${ }^{2}$ Department of Mycobacteriosis, Oswaldo Cruz Foundation, Rio de Janeiro, Brazil \\ ${ }^{3}$ Department of Pathology, FCM, University of State of Rio de Janeiro, Rio de Janeiro, Brazil \\ ${ }^{4}$ Laboratory of Biology Structural, Oswaldo Cruz Foundation, Rio de Janeiro, Brazil \\ ${ }^{5}$ Department of Microbiology and Parasitology, Federal Fluminense University (UFF), Rio de Janeiro, Brazil
}

Received 18 October 2009; revised 21 December 2009; accepted 24 December 2009.

\begin{abstract}
Monoxenous trypanossomatids protozoa are not believed to cause in vivo infection in vertebrate hosts throughout their life cycle. However, there are reports mentioning some cases of HIVpositive patients who have presented opportunistic infections caused by these protozoa. Recently, we have demonstrated the in vitro infection of mouse dermal fibroblasts by these protozoa. The aim of the present work is to investigate the possibility of Crithidia deanei, a endosymbiont-bearing monoxenous trypanossomatid, infect BALB/c mice under or not Dexamethasone treatment. To attend it, distinct gro- ups of adult BALB/c mice were immunosuppressed with $50 \mathrm{mg} / \mathrm{kg}$ of Dexamethasone. This immunosuppressor was administered 24 hours before infection and daily, for 15 days after $C$. deanei inoculation. Control groups: $C$. deanei-inoculated animals but non-immunosuppressed and non-inoculated animals but immunosuppressed were also used. Light Microscopy analysis revealed an infection process characterized by the presence of the trypanossomatid inside dermal cells in the groups studied. The experimental inoculation resulted in a non-lethal infection characterized by the presence of the trypanossomatid inside dermal cells in the normal BALB/c mice, but notably, in the $C$. deanei-inoculated immunosuppressed group. These preliminary results lead to the following conclusions: 1) $C$. deanei is able to infect normal BALB/c mice; 2) the immunosupressed mice seemed to be more susceptible to the $C$. deanei infection compared to the control group.
\end{abstract}

Besides $C$. deanei in dexamethasone-immunosuppressed mice provides a useful model for studies of monoxenous trypanosomatids 'in vivo' infection, resembling that one presumably occurring in imunodeficient individuals with AIDS.

Keywords: Monoxenous Trypanossomatid; 'In Vivo' Infection; Immunosuppression

\section{INTRODUCTION}

Trypanossomatids parasitize a diverse range of hosts including animals, plants and protists [1]. Some of them, such as Trypanosoma and Leishmania, are heteroxenous and are ethiological agents of serious diseases in humans and experimental animals. Others are a monoxenous and are mostly found in insects [2]. Monoxenous trypanosomatids had never been confirmed as pathogenic in vertebrate host. However, there is one report of trypanosomatid, other than Trypanosoma and Leishmania, in some opportunistic cutaneous infections in immunocompromised individuals [3] or those without any previous history of immunodepression [4]. In addition, our group was pioneer in proving the infection of mouse dermal fibroblasts by two different monoxenous trypanosomatid species - Crithidia deanei and Herpetomonas roitmani [5]. Although some of these trypanosomatids were classified as a divergent member of the Leishmania genus [6], a visceral leishmaniasis-like infection was described in an HIV-positive patient as caused by Leptomonas pulexsimulantis, a monoxenous trypanosomatid found in dog's flea [3], suggesting that monoxenous protozoa can be considered opportunistic agents in immunocompromised individuals. Therefore, 
we investigated the ability of $C$. deanei to infect vertebrate host. For that purpose, we have used BALB/c mice under or not Dexamethasone treatment as an experimenttal model, based on a previous report of mouse dermal fibroblasts infection by $C$. deanei and $H$. roitmani [5].

\section{MATERIALS AND METHODS}

Parasite culture. Crithidia deanei was kindly provided by Dr. M. Auxiliadora de Souza (Trypanosomatids Collletion of the Oswaldo Cruz Institute, Rio de Janeiro, Brasil). The monoxenous were kept at $28^{\circ} \mathrm{C}$ with serial passages at $48 \mathrm{~h}$ intervals in Warrens' medium [7] containing $10 \%$ fetal calf serum.

Experimental animal infection. Female 8-week old $\mathrm{BALB} / \mathrm{c}$ mice (Nau, Instituto de Biologia/UFF) were used. Animals housed in standard conditions were treated with Dexamethasone $\left(\right.$ Azium $\left.^{\mathrm{e}}\right)$ [8] 24 hours before infection with $C$. deanei. After infection with $10^{7}$ 2-day-old promastigotes $C$. deanei by subcutaneous route (hind foot pad) - day 0 , dexameth-asone $50 \mathrm{mg} / \mathrm{kg}$ was administered daily, for 15 days. Four BALB/c mice group were used: control without dexamethasone; control with dexamethasone; $C$. deanei-inoculated with dexamethasone and $C$. deanei-inoculated without dexamethasone (Table 1). A determined number of mice from each group were euthanasiated at $6 \mathrm{~h}, 1 \mathrm{~d}, 2 \mathrm{~d}, 3 \mathrm{~d}$, d 7 and d 15 after $C$. deanei inoculation. At each control point, mice were weighted and parasite burdens were determined in foot pad by histological analysis.

Histological analysis. Specimens of foot pad were fixed in $10 \%$ buffered formalin. After dehydration in graded ethanol, the tissues were embedded in paraffin and, then, processed routinely as previously reported [9]. $5 \mu \mathrm{m}$ thick sections were obtained with a Leica microtome. After that, they were collected on glass slides for Hematoxilin-Eosin (HE) staining. The tissues samples infected or not were observed at least 400 randomly selected cells at $1000 \times$ magnification, using a Zeiss photomicroscope.

\section{RESULTS}

Clinical finding's. No mortality, weight loss or clinical signs were observed in mice infected with either dexamethasone or not.

Macroscopy findings. Both groups C.deanei-inoculated immunosuppressed mice and not inoculated immunosuppressed mice displayed splenomegaly and heaptomegaly.

Histological analysis. Through light microscopy the morphological analysis just of the foot pad was done. At necropsy, parasites were found in the foot pad from the mice inoculated with $C$. deanei, regardless immunosupressed or not. In the Dexamethasone treated-controls groups (in the absence of $C$. deanei inoculation), no histological and inflammatory reations of the foot pad were observed until d15 (Figure 2(e1)).

Surprisingly, in both experimental design-in the presence or not of dexamethasone, $C$. deane $i$ was infective to BALB/c mice (Figure 1 and 2), but, notably, in the immunosupressed BALB/c mice (Figure 2).

Using light microscopy, it observed $C$. deanei-infected mouse dermal cells after $24 \mathrm{~h}$ infection (Figures 1(a1) and (a2)). On the 2nd post infection day, $C$. deanei was also observed within mice dermal cells (Figures 1(b1) and (b2)). and, between whiles, extracellular parasites were seen (Figure 1(b1)). A large numbers of parasites were clearly present in the dermal cells after the third post-infection day (Figures 1(c1) and (c2)). Although it was possible to observe $C$. deanei within the dermal cells, their mechanism of entrance is still not clear as it can involve phagocytosis, penetration in the cell or inducing membrane invagination. Anyway, one mechanism of the $C$. deanei-infection might be through sincicious formation from the host cells as the image of the Figures 1(c1) and (c2) suggest. After 7 days of infection it still can observe parasites present in dermal cells $C$. deanei-infected mice (Figures 1(d1) and (d2)). At this time, some extracellular parasites were still seen (Figures 1(d1) and (d2)).

After 15 days of infection, the light microscopy still revealed intracellular forms of $C$. deanei as well as some extracellular forms of this parasite attached to the dermal cells surface (Figures 1(e1) and (e2)).

In the controls groups (in the absence of $C$. deanei inoculation and presence of dexamethasone) no histologycal and inflammatory reactions of the foot pat were observed until day 15 (Figure 2(e1)).

Interestingly, the kinetics of infection in foot pad from C. deanei-inoculated Dexamethasone immunosuppressed mice showed parasites as early as $6 \mathrm{~h}$ in the subcutaneous tissues (Figures 2(a1) and (a2)). Notably, the most exuberant $C$. deanei-infection was observed in the presence of Dexamethasone on the first day of infection (Figures 2(b1) and (b2). In the meanwhile, it can clearly observe a $C$. deanei within a vacuole (Figure 2(b2)). On the following day, it can still observe a large numbers of $C$. deanei inside the cells (Figures 2(c1) and (c2)). In this time of infection, similar to the findings on the previous day, it can see that each parasite occupies its own vacuole (Figures 2(c1) and (c2)). The image of $C$. deanei inside 
Table 1. Distribution of the experimental groups according to the animals number e the respective data of necropsy.

\begin{tabular}{|c|c|c|c|c|c|c|}
\hline \multirow{2}{*}{ Groups } & \multicolumn{6}{|c|}{ Animals number / time of necropsy } \\
\hline & $6 \mathrm{~h}$ & $24 \mathrm{~h}$ & $48 \mathrm{~h}$ & $72 \mathrm{~h}$ & day 7 & day 15 \\
\hline I (C. deanei-inoculated DMT treated mice) & 2 & 2 & 2 & 2 & 2 & 2 \\
\hline II (C. deanei-inoculated mice) & 2 & 2 & 2 & 2 & 2 & 2 \\
\hline III (DMT treated mice) & 1 & 1 & 1 & 1 & 1 & 1 \\
\hline IV (not DMT treated and not $C$. deanei inoculated mice)-Control Groups & 1 & 1 & 1 & 1 & 1 & 1 \\
\hline Total & 6 & 6 & 6 & 6 & 6 & 6 \\
\hline
\end{tabular}

- DMT-Dexamethasone $50 \mathrm{mg} / \mathrm{kg}$.

- In a total 36 animals were used.

- The animals were euthanazed according to the rules of ethical comitê (Comissão de ética no uso de animais (CEUA- FIOCRUZ) P8317 ação: 1201 no. P024705).

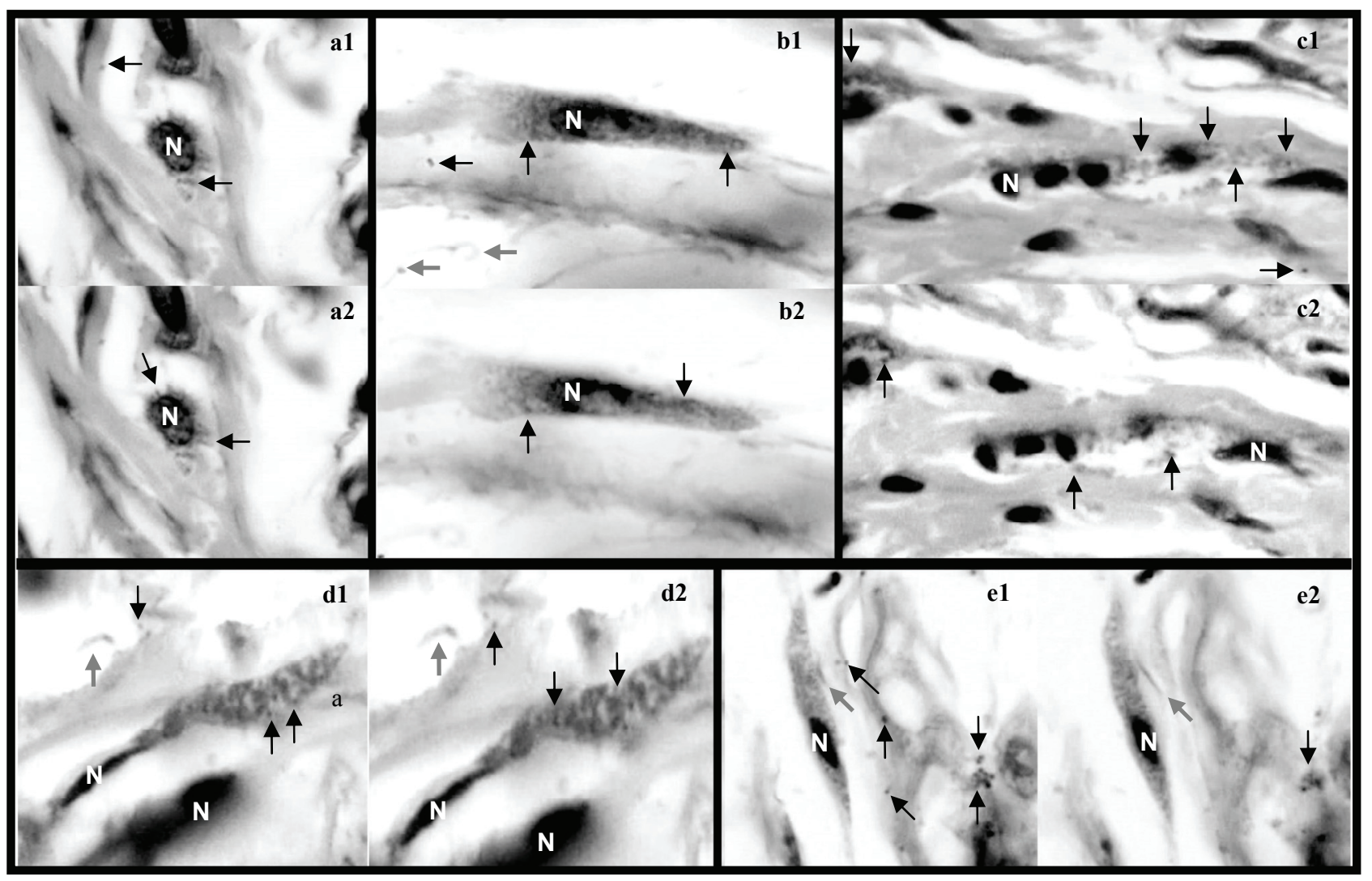

Figure 1. Analysis by light microscopy showing $C$. deanei interaction with Balb/c mouse. Pictures were taken in a two different plans from the same field (e.g. a1 and a2, etc...) in order to show whole extension of cell infection. Representative sections from skin samples of 24h (a1 and a2); 48h (b1 and b2); 72h (c1 and c2); 7 days (d1 and d2) and 15 days (e1 and e2) C. deanei post-infection (original magnification x 100). Grey Arrow shows some free $C$. deanei extracellular forms (b1; $\mathrm{d} 1$ and $\mathrm{d} 2$ ) as well as $C$. deanei extracellular forms attached to the dermal cells surface (e1 and e2). Dark arrow show multiple $C$. deanei-infected dermal cells. Note the presence of sincicious formation in $\mathrm{c} 1$ and $\mathrm{c} 2 . \mathrm{N}=$ Dermal cells nucleous. 


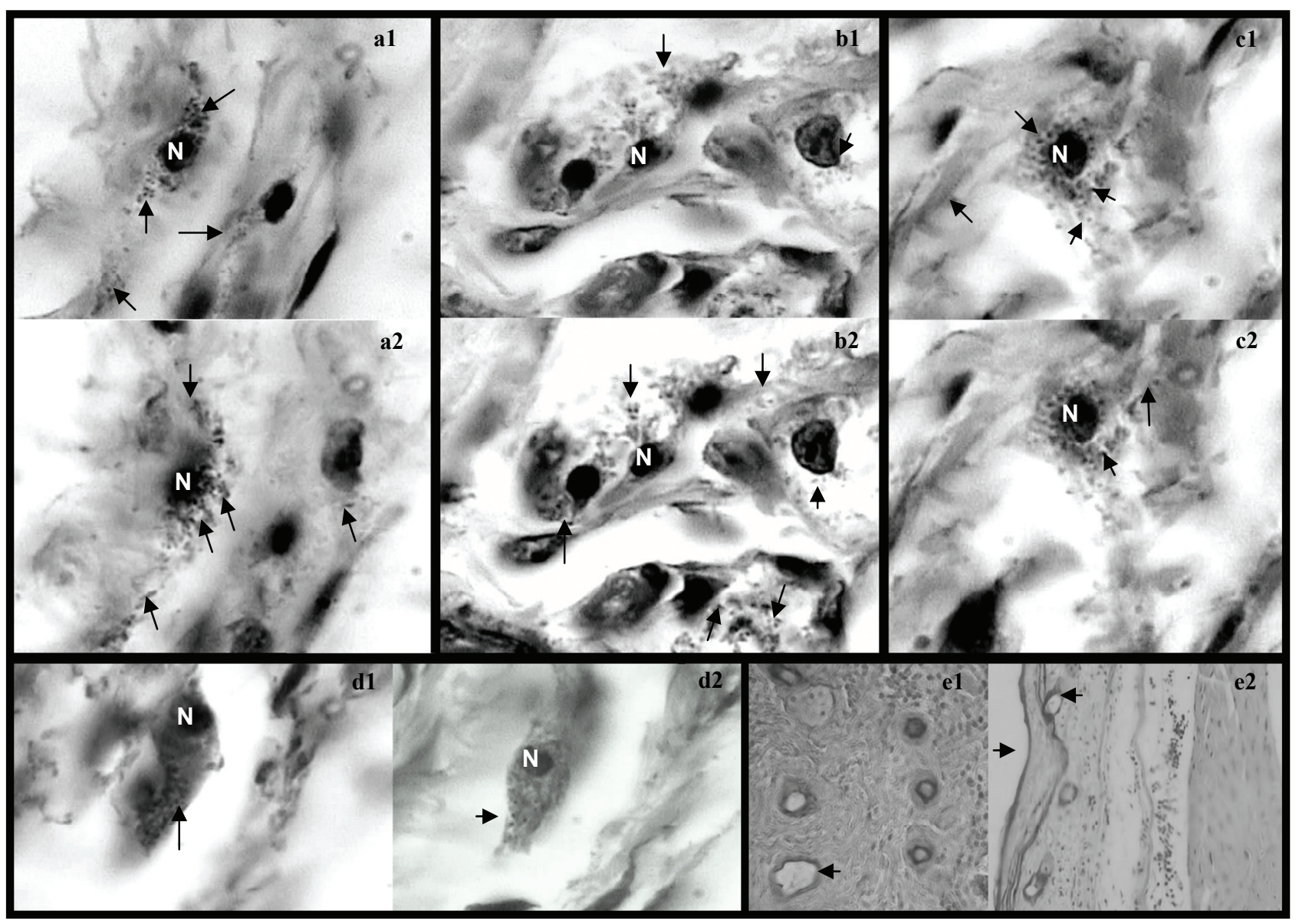

Figure 2. Analysis by light microscopy showing $C$. deanei interaction with dexamethasone immunosuppressed Balb/c mouse. Pictures were taken in a two different plans from the same field (e.g. a1 and a2, etc...) in order to show whole extension of cell infection. Representative sections from skin samples of $6 \mathrm{~h}$ (a1 and a2); 24h (b1 and b2); 48h (c1 and c2); 72 h(d1 and d2) C. deanei post-infection (original magnification x 100). Dark arrow show multiple strongly $C$. deanei-infected dermal cells. Occasionaly, some parasites seemed to be clearly envolved by a vacuole (a2, b2, c1, c2 and d2). Controls groups 15 days after dexamethasone treatment or not (e1: dexamethasone-immunosuppressed Balb/c mouse; and e2: normal Balb/c mouse; original magnification $(\mathrm{e} 1) \times 50$ and $(\mathrm{e} 2)$ $\times 10) . \mathrm{N}=$ Dermal cell nucleous.

vacuoles continues to be seen in the third day of infection (Figures 2(d1) and (d2)). Here some tissue degradation was also observed (Figures 2(d1) and (d2)). Interestingly, at the last days of infection time (7 and 15 days) in immunosupressed BALB/c mice, no parasites were found contrasting to some tissue alterations which were observed (data not shown).

\section{DISCUSSION}

Several clinical cases suggesting that monoxenous trypanosomatids could be implicated in human infections have been described in the last years. They have been emerging as possible opportunistic pathogens in imunocompromised individuals. An unusual Leishmania-like parasite was found in a HIV-positive patient with symp- toms of Leishmania infection [10]. Despite the previous-mentioned data, genotypic and phenotypic characterization showed that a flagellate parasite, found in the bone marrow of a Brazilian HIV-positive patient presenting a visceral leishamniasis-like reaction, was indeed a monoxenous trypanosomatid, although no tissue invasion could be detected [3]. Surprinsingly, a new case of cutaneous infection by a presumed monoxenous trypanosomatid was reported in the island of Martinique; however, the individual had no history of immunosuppression, particularly HIV infection [4].

As stated earlier, Santos et al. (2004) first reported that endosymbiont-bearing trypanosomatid $C$. deanei and Herpetomonas roitmani are able to infect mouse dermal-derived fibroblasts while Crithidia fasciculate and Herpetomonas samuelpessoai (trypanossomatid 
endosimbiont free) did not infect. It is also of interest to observe that both $C$. deanei and $H$. roitmani can be resistant to lysis mediated by the complement system. In contrast, $H$. samuelpessoai and $C$. fasciculate displayed $100 \%$ of lysis after incubation with the complement system [5]. The symbionts of $C$. deanei can influence the phagocytosis of these parasites by macrophages as have been presented by [11]. And, most recently, [12], reported the infection of HIV-1-infected prim- ary human macrophages by Blastocrithidia culicis (another endosymbiont-bearing monoxenous trypanosomatid). Our present data further emphasize the large capacity of $C$. deanei to infect vertebrate host and reinforce the idea that monoxenous trypanosomatids present low host specifity $[2,13,14]$. As demonstrated by our work, $C$. deanei can readily infect normal $\mathrm{BALB} / \mathrm{c}$ mice by subcutaneous route and infection persist in the dermal cells for 15 days. These are very interestingly results, since we have previously reported the "in vitro" $C$. deaneiinfection of dermal cells obtained from a different specie of mouse-the Swiss mouse [5]. Besides, as observed in our present work, extracellular forms of $C$. deanei are displayed in dermal tissue of the BALB/c mice (Figures 1(b1), (d1) and (d2)). This fact is interesting to be mentioned since it might suggest that, after intracellular $C$. deanei cycle, these parasites leave the host cell and, after that, appear in the extracellular medium (in a flagellate form) to re-infect others dermal cells. Taken together, these evidences reinforce the idea that monoxenous trypanosomatids are able to infect and to survive once reaching the vertebrate host. Over and again, we demonstrated the infection of BALB/c mice, but, a much more pronounced $C$. deanei-infection in a different experimental design: in Dexamethasone-immunodepressed mice (Figure 2). Through its limphopenic activity, specially about $\mathrm{T}$ cell production [15], the dexamethasone can reduce the mechanisms of anti-parasite effect of immune system and it might explain the increase of susceptibily to $C$. deanei infection observed in all immunosuppressed animals. The important survival of the parasite in the murine experimental host contrast strikingly with the weak clinical-pathological effects observed with absence of lymphocytic infiltrates in parasitized foot pad. This can be paralleled to that observed during human visceral leishmaniasis where patent infections with parasite dissemination are frequently associated with $\mathrm{T}$ cell unresponsiveness to Leishmania antigen [16], while cure is accompanied with restoration of the cellular response $[17,18]$. Although monoxenous trypanosomatids in humans are more correlated to opportunistic parasites, our work is pioneer in demonstrating that $C$. deanei is able to infect normal mice (whithout dexamethasone treatment). Our findings corroborate to the reports of [4], who also found monoxenous tripanosomatids in a nonimmunocompromised individual though in a localized skin lesion. Besides, our previous report demonstrated the monoxenous trypanosomatid infection by dermal cells isolated from skin of normal Swiss mice [5]. Neverthless, our data shows that the infection of $C$. deanei by dexamethasone-treated mice, although earlier proeminent at the beginning of the time of infection (Figures 2(a),(b)), could not be followed longer, since the dermal cells seemed to be degenerated (data not shown). These results suggest that $C$. deanei might induce dermal cells degeneration. Most recently, [19] reported that $C$. deanei was able to induce fibroblasts lysis.

Besides the interaction of monoxenous trypanossomatids with vertebrate cells, the literature have also mentioned some results obtained from the interaction of these trypanossomatids with invertebrate cells. Then, [20,21], reported the colonization of Aedes aegypti midgut by the endosymbiont-bearing trypanosomatid Blastocrithidia culicis and $C$. deanei respectively.

Considering the colonization of hematophagous insects by monoxenous trypanosomatids and their low host specificity, human cases of infection with lower trypanosomatids could have been largely underestimated until now due to their morphological similarity with Leishmania species. This emphasizes the relevance of enzymatic characterization, whenever possible, of all Leishmania-like parasites isolated from skin or visceral lesions of patients with or not immunosuppression history. Taken together, these reports reinforce the idea of the urgent need of elucidating the epidemiology of these lower trypanosomatids that so far remains poorly known.

\section{ACKNOWLEDGEMENTS}

We thank FAPERJ, CNPq, UFF and FIOCRUZ for the finantial support.

\section{REFERENCES}

[1] Vickermank, K. (1994) The evolutionary expansion of the trypanossomatid flagellates. International Journal for Parasitology, 24(8), 1317-1331.

[2] Wallace, F. G. (1966) The trypanosomatid parasites of insects and arachnids. Experimental Parasitology, 18(1), 124-193.

[3] Pacheco, R.S., Marzochi, M. and Pires, M. (1998) Parasite genotypically related to a monoxenous trypnosoamtid of dog's flea causing opportunistic infection in HIVpositive patient. Memórias do Instituto Oswaldo Cruz, 93 (4), 531-537.

[4] Boisseau-Garsaud, A.M., Cales-Quist, D. and Desbois, N. (2000) A new case of cutaneous infection by a presumed monoxenous trypanosomatid in the island of Mar- 
tinique (French WEst Indies). Transactions of the Royal Society of Tropical Medicine and Hygiene, 94(1), 51-52.

[5] Santos, D.O., Bourguignon, S.C. and Castro, H. C. (2004) Infection of mouse dermal fibroblasts by the monoxenous trypanosomatid Protozoa Crithidia deanei and Her- petomonas roitmani. Journal of Eukaryotic Microbiology, 51, 570-574.

[6] Noyes, P., Pratlong, F. and Chance, M. (2002) A previously unclassified trypnosomatid responsible for human cutaneous lesions in Martinique (French West Indies) is the most divergent member of the genus Leishmania ss. Parasitology, 124(Pt 1), 17-24.

[7] Warren, L.G. (1960) Metabolism of schizotrypanumcruzi Chagas. 1. Effect of culture age and substrate concentration on respiratory rate. Journal of Parasitology, 46, 529539.

[8] Lallo, M.A., Santos, M.J. and Bondam, E.F. (2002) Experimenatal encephalitozoon cuniculi infection in dexamethasone-immunosuppressed mice. Revista de Saúde Pública. 36(5), 621-626.

[9] Santos, D.O, Castro, H.C. and Bourguignon, S.C. (2007) Expression of B7-1 costimulatory molecule in patients with multibacillary-leprosy and reactional states. Clinical and Experimental Dermatology, 32(1), 75-80.

[10] Jiménez, M.L., lópez-Vélez, R. and Molina, R. (1996) HIV coinfection with a currently non-pathogenic flagellate. Lancet, 347(8996), 264-265.

[11] Rozenthal, S., De Carvalho, T.U. and De Souza, W. (1987) Influence of the endosymbiont on the interaction of Chrithidia deanei with macrophages. Microscopy Electron Biology Cell, 11, 167-179.

[12] Barreto-de-Souza, V., Xavier Medeiros, T. and Machado Motta, M.C. (2008) HIV-1 infection and HIV-1 Tat protein permit the survival and replication of a non-pathogenic trypanosomatid in macrophages through TGF beta 1 production. Microbes and Infection, 10(6), 642-649.

[13] Podlipaev, S.A. (2001) The more insect trypanosomatids under study-the more diverse Trypanosomatidae appears.
International Journal for Parasitology, 31(5-6), 648-652.

[14] Podlipaev, S.A., Strurm, N.R. and Fiala, I. (2004) Diversity of insect trypanossomatids assessed from the splice leader RNA and 5S rRNA genes and intergenic region. Journal of Eukaryotic Microbiology, 51(3), 283290.

[15] Diasio, R.B. and LoBuglio, A.F. (1996) Immunomodulators: Immunosuppressive agents and immunostimulants the pharmacological basis of therapeutics. 9th Edition, Mcgraw Hill, London.

[16] Ghalib Ghalib, H.W., Piuvezam, M.R. and Skeiky, Y.A.W. (1993) Interleukin 10 production correlates with pathology in human Leishmania donovani infections. Journal of Clinical Investigation, 92(1), 324-329.

[17] Carvalho, E.M., Bacellar, O. and Brownell, C. (1994) Restoration of the IFN-g production and lymphocyte proliferation in visceral leishmaniasis. Journal of Immunology, 152(12), 5949-5956.

[18] Mary, C., Lamouroux, D. and Dunan, S. (1992) Western blot analysis of antibodies to Leishmania infantum antigens: potencial of the 14-KD and 16-KD antigens for diagnosis and epidemiologic purposes. American Journal of Tropical Medicine and Hygiene, 47(6), 764-771.

[19] Matteoli, F.P., D'Avila-Levy, C.M. and Santos, L.O. (2009) Roles of the endosymbiont and leishmanolysinlike molecules expressed by Crithidia deanei in the interaction with mammalian fibroblasts. Experimental $\mathrm{Pa}$ rasitology, 121(3), 246-253.

[20] Corrêa-da Silva, M., Fampa, P. and Lessa, L.P. (2006) Colonizatin of Aedes aegypti midgut by the endosymbiont-bearing trypanosomatid Blastocrithidia culicis. Parasitology Research, 99(4), 384-391.

[21] D'Avila-Levy, C.M., Santos, L.O., Marinho, F.A. and Matteoli, F.P. (2008) Crithidia deanei: Influence of parasite gp63 homologue on the interaction of endosymbiont-harbouring and aposymbiotic strains with Aedes aegypty midgut. Experimental Parasitology, 118(3), 345353. 